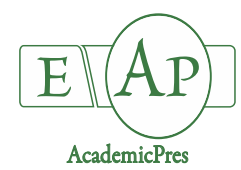

Sumalan RL, Muntean C et al. (2020)

Notulae Botanicae Horti Agrobotanici Cluj-Napoca 48(4):2095-2113

DOI: $10.15835 / 48412160$

Research Article

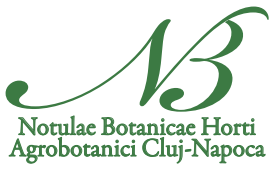

\title{
The cup plant (Silphium perfoliatum L.) - a viable solution for bioremediating soils polluted with heavy metals
}

\section{Radu L. SUMALAN ${ }^{1 a *}$, Cornelia MUNTEAN²b, Ana KOSTOV³, Daniel KRŽANOVIĆ ${ }^{3}$, Noemi L. JUCSOR ${ }^{1}$, Sorin I. CIULCA ${ }^{1}$, Renata M. SUMALAN ${ }^{1}$, Marius GHEJU'2, Mariana CERNICOVA-BUCA ${ }^{4}$}

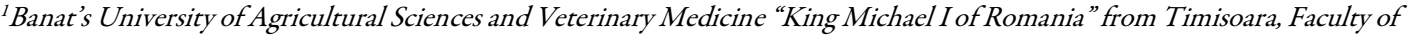 \\ Horticulture and Forestry, 119 Calea Aradului, 300645, Timisoara, Romania; sumalanagro@yahoo.com ("corresponding author); \\ noemi_larisa@yahoo.com;c_i_sorin@yahoo.com; srenata_maria@yahoo.com \\ ${ }^{2}$ Politehnica University Timisoara, Faculty of Industrial Chemistry and Environmental Engineering, 6 Bv. Vasile Parvan, 300223 , \\ Timisoara,Romania; cornelia.muntean@upt.ro;marius.gheju@upt.ro \\ ${ }^{3}$ Mining and Metallurgy Institute Bor, 35 Zeleni bulevar, 19210, Bor, Serbia; ana.kostov@irmbor.co.rs; \\ daniel.krzanovic@irmbor.co.rs \\ ${ }^{4}$ Politehnica University Timisoara, Faculty of Communication Sciences, 2/A Str. Traian Lalescu, 300223, Timisoara \\ Romania; mariana.cernicova@upt.ro \\ ${ }^{2, b}$ These authors contributed equally to this work and should be considered co-first authors
}

\begin{abstract}
Heavy metal pollution, manifested by the accumulation, toxicity and persistence in soil, water, air, and living organisms, is a major environmental problem that requires energetic resolution. Mining tailing areas contain metal minerals such as $\mathrm{Cu}, \mathrm{Zn}, \mathrm{Pb}, \mathrm{Cr}$ and $\mathrm{Cd}$ in high concentrations that pollute the environment and pose threats to human health. Phytoremediation represents a sustainable, long-term, and relatively inexpensive strategy, thus proving to be convenient for stabilizing and improving the environment in former heavy metal-polluted mining sites. This study presents the bioremediation potential of Silphium perfoliatum L. plants, in the vegetative stages of leaf rosette formation, grown on soil polluted with heavy metals from mining dumps in Moldova-Noua, in the Western part of Romania. The bioaccumulation factor (BAF), translocation factor (TF), metal uptake (MU) and removal efficiency (RE) of $\mathrm{Cu}, \mathrm{Zn}, \mathrm{Cr}$ and $\mathrm{Pb}$ by $S$. perfoliatum plants were determined in a potted experiment in controlled environmental conditions. The reference quantities of heavy metals have been determined in the studied soil sample. The experiment followed the dynamics of the translocation and accumulation of heavy metals in the soil, in the various organs of the silphium plants, during the formation of the leaf rosette (13-18 BBCH). The determination of the amount of heavy metals in soil and plants was achieved by the method of digestion with hydrochloric and nitric acid 3/1 (v/v) quantified by atomic absorption spectroscopy (AAS). The obtained experimental results demonstrate that the substrate has a high heavy metal content being at the alert threshold for $\mathrm{Zn}(260.01$ $\mathrm{mg} \mathrm{kg}{ }^{-1}$ in substrate compared with alert threshold $\left.300 \mathrm{mg} \mathrm{kg}^{-1}\right)$ and at intervention thresholds for other metals ( $\mathrm{Cu}-234.66$ $\mathrm{mg} \mathrm{kg}-1 / 200 \mathrm{mg} \mathrm{kg}^{-1} ; 299.08 \mathrm{mg} \mathrm{kg}^{-1} / 300 \mathrm{mg} \mathrm{kg}^{-1}$ and $\left.\mathrm{Pb}-175.18 \mathrm{mg} \mathrm{kg}^{-1} / 100 \mathrm{mg} \mathrm{kg}^{-1}\right)$. The average concentration of the metals determined in dynamics in the dry biomass of plants varied between roots, petioles, and laminas. The root is the main accumulator for $\mathrm{Cu}$ and $\mathrm{Cr}\left(\mathrm{Cu}-37.32 \mathrm{mg} \mathrm{kg}^{-1}-13 \mathrm{BBCH}\right.$ to $43.89 \mathrm{mg} \mathrm{kg}^{-1}-15 \mathrm{BBCH}$ and $80.71 \mathrm{mg} \mathrm{kg}^{-1}-18 \mathrm{BBCH}$; Cr $-57.43 \mathrm{mg} \mathrm{kg}^{-1}-13 \mathrm{BBCH}$ to $93.36 \mathrm{mg} \mathrm{kg}^{-1}-18 \mathrm{BBCH}$ ), and for $\mathrm{Zn}$ and $\mathrm{Pb}$ the lamina seems to carry the same function. Preliminary results show that Silphium perfoliatum may be a viable alternative in the bioremediation and treatment of heavy metal-contaminated area.
\end{abstract}


Keywords: bioaccumulation factor; contaminated areas; cup plant; phytoextraction; removal efficiency translocation factor

\section{Introduction}

Soil pollution with heavy metals is an environmental problem that manifests itself globally. The presence of heavy metals in soils is mainly due to anthropogenic activities such as mining, steel casting, medical waste, chaotic application of pesticides and fertilizers, use of wastewater for irrigation, burning of leaded gasoline, coal, etc. (Alloway et al., 2000; Yoon et al., 2006; Cao et al., 2009; Huang et al., 2017; Zhang et al., 2017, 2018 a).

Heavy metals have negative effects on the health of humans and animals mainly due to the tendency to bio-accumulate in the food chain and their long-term persistence in the environment (Yoon et al., 2006; Azimi et al., 2017; Shen et al., 2019; Sall et al., 2020).

With the rapid development of mining activities, landscape changes as well as environmental pollution have become even more serious. The intensive mineral extraction has generated a large amount of waste accumulated in waste and dumps (Ma et al., 2015, Demková et al., 2017). Without proper management, the abandoned mines and accumulated residues are the source of heavy metal pollution, which is washed away and can contaminate all environmental components (Liakopoulos et al., 2010; Li et al., 2014, Yang et al., 2018).

Soil contamination with heavy metals because of mining operations is present in Europe on fairly large areas, with an undesirable impact on the environment in particular and the quality of life in general. This is also true for Romania, where mining has been a core economic branch providing more than 1 million jobs in the 14 mining areas located in 16 counties. After 2000, the mining production has dropped dramatically, leaving behind depopulated areas, abandoned mines, waste dumps and tailings ponds with high heavy metal content. Some of the shutdown mines have become, over time, true 'environmental bombs' because the funds allocated for closing, rehabilitating the surfaces, and restoring them to the natural/economic circuit have been insufficient (https://energyindustryreview.com/metals-mining/mining-industry-left-without-miners-lamp/).

Decanting ponds as well as waste dumps through low stability, high content of metal ions and flotation agents produce disastrous and long-term negative effects on air quality, soils, surface water and groundwater (Hudson-Edwards et al., 2011).

These mining decanting areas contain metal minerals in quite large quantities, the best known of which, acting as pollutants are; arsenic $(\mathrm{As})$, lead $(\mathrm{Pb})$, mercury $(\mathrm{Hg})$, chromium $(\mathrm{Cr})$, zinc $(\mathrm{Zn})$, cadmium $(\mathrm{Cd})$, copper $(\mathrm{Cu})$, and nickel (Ni) (Hansda et al., 2014; Pratush et al., 2018).

In recent decades, numerous technologies have been tested and applied to reduce the large concentrations of heavy metals in the environment (e.g. chemical precipitation and coagulation, ion exchange, reverse osmosis, membrane filtration, soil washing, etc.) but most of these methods are not practical because of the environmental danger, high costs and low efficiency (Gavrilescu, 2004; Olguín and Sánchez- Galván, 2012; Wang and Sun, 2013; Martín-Lara et al., 2014; Hanif and Bhatti, 2015; Choińska-Pulita et al., 2018).

The growing need to remediate contaminated, safe and low-cost sites has led to the search for solutions through the development of green, cost-effective and environmentally friendly biotechnology, such as phytoremediation, which relies on the potential of some plant species to extract, fix and detoxify metal pollutants (Nowack et al., 2006; Ali et al., 2013; Pandey et al., 2015; Rezania et al., 2016).

Heavy metals present in high concentrations in the surface layer of soil directly influence the growth and development of plants in the affected areas (Zhang et al., 2018b). Like other stressors, heavy metal toxicity induces oxidative stress and modulates the expression of genes involved in stress tolerance (Shri et al., 2009; Tripathi et al., 2012; Dubey et al., 2018).

Considering the acute toxicity of some heavy metals, it is necessary to develop quickly cheap, efficient, sustainable and sustainable methods that ensure the accumulation, dissipation, immobilization and degradation of pollutants by the use of plant organisms. These processes are based on phytoremediation 
techniques (phytoextraction, rhizofiltration, phytovolatilisation, phytostabilization, hydraulic control, rhizodegradation and phytodegradation of heavy metals).

Thus, the identification of plant species with the ability to tolerate (and concentrate in their biomass) the high levels of these heavy metals becomes an important factor in phytoremediation studies (Yu et al., 2013; Singh et al., 2015).

To date, more than 500 species of plants capable of accumulating heavy metals have been identified (Baker and Brooks, 1989; Kramer, 2010; Hemen, 2011). Most of these are extremely specific to a particular type of metal, have low accumulation capacity, slow growth speed and thorough care technologies for multiplication (Gleba et al., 1999), thus making them unsustainable for large-scale use.

The presence of several types of heavy metals in the same soil determines their interaction with combined ecological effects, complicating the phytoremediation process (Fang et al., 2012). The identification of plant species with high biomass accumulation intensity, together with the ability to tolerate and accumulate several types of metals, is an essential feature of research into phytoremediation of soils polluted with heavy metals (Yu et al., 2015).

There are numerous studies in the literature showing different plant species with the ability to accumulate heavy metals from polluted soils. Starting with Solanum nigrum (Wei et al., 2010), Linum usitatissimum (Bjelkova et al., 2011), Pinus silvestris (Ostrowska et al., 2006), Ricinus communis (Zhi-Xin et al., 2007) to grasses (Zhang et al., 2010) and brassicacea (Palmer et al., 2001) accumulating cadmium (Cd) la Allium fistulosum, Pteris cretica (Cho et al., 2009), Ricinus communis (Zhi-Xin et al., 2007), Phragmites australis (Weis and Weis, 2004) and Amorpha fruticose (Shi et al., 2011) as lead accumulators (Pb), or Brassica Rapa (Meers et al., 2005) and Vetiveria zizanoides (Andra et al., 2009) zinc accumulators ( $\mathrm{Zn}$ ) there are numerous species whose bioremediation potential is still insufficiently known (Chirakarra et al., 2016).

Among these species, presented as a potential hyperaccumulator, is Silphium perfoliatum (the cup plant). It is known as the perennial herbaceous plant, with high capacity to accumulate biomass and high tolerance to abiotic stressors, extremely versatile and adaptable to extreme environmental conditions (Jucsor and Sumalan, 2018). Figas et al. (2015) state that there are some studies confirming the potential of use of the species for the rehabilitation of degraded land, by phytoremediation (Klimont, 2007; Majtkowski, 2010). It can also be used as a potential species for the phytostabilization of cadmium in soil (Zhang et al., 2010). We note that the most important use of silphium biomass is as a source of renewable energy through the production of biogas.

Silphium perfoliatum L. (cup plant; rosinweed, silfie) is a multiannual herbaceous plant of the genus Silphium family Asteraceae, native to the North American prairies. In the first year it forms a rosette of leaves with a diameter of $60-70 \mathrm{~cm}$ that covers the soil almost completely. In the $2 \mathrm{nd}$ year the plant forms multiple stems, floriferous, 1.2 to $3 \mathrm{~m}$ with 8 to 14 pairs of leaves arranged alternately at intervals of $10-18 \mathrm{~cm}$. On the island of the alternating leaves is concreted, forming a cup that the stem seems to pierce, hence the alternative colloquial name: the cup plant.

The objective of our study was to evaluate the adaptability and phytoremediation capacity of $S$. perfoliatum $L$. plants grown on soils polluted with heavy metals, from the dumps of the former mines in Moldova-Noua in the Western part of Romania. The distribution of heavy metals extracted in the root, petiole and the leaf tongue were analyzed, quantified, and compared with respect to bioaccumulation (BAF), translocation (TF) factors, as well as the metal uptake (MU) and removal efficiency (RE), of heavy metals.

\section{Materials and Methods}

\section{Description of the study site}

Moldova Noua is a settlement in Romania on the territory of which there is an old, abandoned copper mine. The remaining mining residues cause important environmental problems due to pollution. 
Soil samples were collected (0-30 $\mathrm{cm}$ depth) from a mining area situated in Moldova Noua (44 $44^{\prime}$ $15.00^{\prime \prime} \mathrm{N} / 21^{\circ} 40^{\prime} 0.98^{\prime \prime} \mathrm{E}$ ) in the southwest of Romania. The soil used for testing originates from the agricultural land in the immediate vicinity of mining tailing sites resulting from the exploitation of copper. 100 $\mathrm{kg}$ of soil were collected from 10 different points located on an area of $5000 \mathrm{sq}$ meters. The collected soil was packed and transported, then it was homogenized and prepared for the initial analyses.

\section{Soil samples pretreatment}

The soil samples prepared for analysis were ground fresh repeatedly, after which they were air-dried under a sterile and moisture-free condition for further processing. The samples were sieved through a 2-mm mesh screen and separated manually in representative quantities $(3 \mathrm{~g})$ for the initial analyses of heavy metal content. This preparation and storage of soil samples for future chemical analyses were carried out according to ISO 11464/2006 (https://standards.iteh.ai/catalog/standards/iso/63199580-e1a0-4537-a141ab923c298e27/iso-11464-2006).

The pot culture experiment was conducted in the laboratory and greenhouse of the Plant Physiology Department, Banat's University of Agricultural Sciences and Veterinary Medicine "King Michael I of Romania" from Timisoara and soil and plant tissue analyses were made in the Laboratory of Environmental Analysis, Research Institute of Renewable Energies, Politehnica University of Timisoara, in spring-summer 2020.

\section{Determination of heavy metal concentration in soil samples}

The soil samples homogenized through coning and quartering were dried at $75^{\circ} \mathrm{C}$ for 48 hours and afterwards they were ground to obtain a fine powder. The soil dried and sifted samples were treated with a solution of hydrochloric acid $(\mathrm{HCl})$ and nitric acid $\left(\mathrm{HNO}_{3}\right)$ in a ratio of 3:1 (v/v). The resulting solution was then cooled, filtered, and diluted with $25 \mathrm{ml}$ of distilled water. The digested liquid was filtered through paper Whatman No. 0.5, and the total heavy metal content of the filtrate was analysed by AAS technique (https://www.iso.org/standard/24010.htm/).

\section{Biological material}

The Silphium perfoliatum L. of the Asteraceae family used for this study is a high-biomass, tolerant to abiotic stress. The nomenclature of the cup plant species conforms to the online resource, IPNI (2020). The seeds used for growing the plants origin from the collection owned by the Plant Physiology Department, Banat's University of Agricultural Sciences and Veterinary Medicine "King Michael I of Romania" from Timisoara.

\section{Experimental procedures}

Before being germinated, the seeds were layered by treatment with low temperatures $\left(3-4^{\circ} \mathrm{C}\right.$ for 4 weeks $)$ to interrupt the longing, then were sterilized in $10 \% \mathrm{NaOCl}$ solution for $20 \mathrm{~min}$ to prevent the apparition of fungi, and then washed several times with distilled water. The seeds were soaked for 24 hours in distilled water for initiating the pre germination process and then they were directly sown in pots with $8 \mathrm{~cm}$ on substrate Bio Plantella Start (black peat $-50 \%$; humanic white peat $-50 \%$ organic fattening $-4 \mathrm{~kg} \mathrm{~cm}^{-1} ; \mathrm{N}-1300-1800 \mathrm{mg}$ $\mathrm{kg}^{-1} ; \mathrm{P}_{2} \mathrm{O}_{5}-150-250 \mathrm{mg} \mathrm{kg}^{-1} ; \mathrm{K}_{2} \mathrm{O}-200-300 \mathrm{mg} \mathrm{kg}^{-1}, \mathrm{pH} 6.2-6.8$ ), produced by Unichem DOO -Slovenia. The pots were placed, until the appearance of the first leaf, in the growth chamber model WiseCube WTH E305 (Witeg Labortechnik GmbH, Germany) at the constant temperature of $20^{\circ} \mathrm{C}$, air relative humidity $80 \%, 12 / 12$ light/dark; the soil humidity has been kept at optimal values by daily watering.

After the seedlings had risen, 120 of them were moved to a greenhouse $\left(26 \pm 3 / 18 \pm 3{ }^{\circ} \mathrm{C}\right.$, day/night; 65 $\pm 5 \%$ air relative humidity and between 10 to 16 hours of light), and at the formation of the second leaf (12 $\mathrm{BBCH}$ ) (Meier et al., 2009), 60 plants, uniform in terms of growth and development stage, were transplanted into 2 -litre capacity pots filled with soil polluted with heavy metals, collected from the mining area Moldova 
Noua. To avoid the loss of mineral elements by leaching, trays were placed under each plant pot and the collected solution was reintroduced into the circuit.

After 10 days of transplantation, with the formation of the third leaf $(13 \mathrm{BBCH})$ analyses were carried out on the content of heavy metals in soil and plants (root, petiole, and leaf limb). Also, the fresh mass of the plant organs and the amount of dry matter were determined, by drying in the oven (Universal Oven UmUF $75 \mathrm{~m}$ plus, Memmert GmbH + Co. KG, Germany) at $105^{\circ} \mathrm{C}$ for $2 \mathrm{~h}$ and then continuously at $80{ }^{\circ} \mathrm{C}$ until achieving a constant dry weight. The following determinations and analyses were made in developmental stages 13 and $15 \mathrm{BBCH}$, i.e. at 3 and 5 leaves. Throughout the experiment the plants were tended and watered to maintain an optimal level of soil humidity (approx. $70 \%$ from field capacity).

The dried plants organs (roots, petioles, and laminas) were calcined to remove their organic part, for the purpose of their subsequent analysis.

The weighed plant material, placed in the melting pot, was heated to carbonization, $550-600^{\circ} \mathrm{C}$, for 5 6 hours, after which the melting pot was allowed to cool in the desiccator, and then the melting pot was weighed again with the resulting ash after carbonization of the plant. The difference between the initial mass of the plant and the mass remaining after calcination represents the loss at calcination.

The dry soil and ash samples resulted from the calcination of the plants samples were extracted with an acid mixture (aqua regia) made by combining concentrated hydrochloric acid and nitric acid in a volumetric ratio 3:1.

Samples of approximately $3 \mathrm{~g}$ of soil or ash to the nearest $0.001 \mathrm{~g}$ were placed into a $250 \mathrm{~mL}$ reaction flask and moistened with approximately $0.5-1 \mathrm{~mL}$ of water. A quantity of $21 \mathrm{~mL}$ of concentrated hydrochloric acid was added, followed by $7 \mathrm{~mL}$ of concentrated nitric acid. The sample was allowed $16 \mathrm{~h}$ at room temperature to permit slow oxidation of the organic matter in the soil. Afterwards, a slow raise of the temperature of the reaction mixture was allowed, until the reflux conditions were reached and maintained for $2 \mathrm{~h}$, ensuring that the condensation area was less than $1 / 3$ of the height of the refrigerant, and then allowed to cool. The contents of the absorption bottle were placed into the reaction flask through the refrigerant, rinsing both the absorption bottle and the refrigerant with a further $10 \mathrm{~mL}$ of nitric acid. The insoluble residue in the reaction flask was let to settle. The relatively free supernatant of the sediments obtained by decanting through a filter paper collecting the filtrate was carefully passed in a $100 \mathrm{~mL}$ volumetric flask. All the initial extract from the reaction flask was passed through the filter paper, and then the insoluble residue on the filter paper was washed with a minimum of nitric acid and collect this filtrate with the first.

The metal ion content in the filtrate were determined by AAS method (Varian SpectrAA 280FS, Agilent Technologies Inc. USA) according with ISO 11047 / 1998 (https://www.iso.org/obp/ui/\#iso:std:iso:11047:ed-1:v1:en).

These determinations were repeated in the phenophases of $5(15 \mathrm{BBCH})$ and 8 leaves $(18 \mathrm{BBCH})$, JuneSeptember 2020, respectively. The number of repetitions was 5 for each parameter determined and at each time.

In order to establish the potential of $S$. perfoliatum plantlets for decontamination of heavy metals polluted soils, different phytoremediation indexes like bioaccumulation factor (BAF), translocation factor (TF), metal uptake (MU) and removal efficiency (RE), were calculated using the formulas (Gupta et al., 2008; Anning et al., 2013; Stanislawska-Glubiak et al., 2015; Anning and Akoto, 2018):

$B A F=$ heavy metal concentration in plant/ heavy metal concentration in soil

$T F=$ heavy metal concentration in leaf/ heavy metal concentration in root

$M U=$ heavy metal concentration in leaf or root $\times$ dry weight of leaf or root $\left(\mathrm{mg} \mathrm{kg} \mathrm{g}^{-1} \mathrm{dw}\right)$

$R E=($ initial heavy metal concentration in soil - final heavy metal concentration in soil) /(initial heavy metal concertation in soil) $\times 100$ 


\section{Statistical procedures}

The data for all analyses and determination were statistically processed using ANOVA, and the means were compared using the least significant difference (LSD) test (Ciulca, 2006). The significance of differences was expressed based on letters, being considered as significant $(p<0.05)$ the differences between means marked with different letters.

\section{Results}

Heavy metals concentration in the experimental substrate

Mean concentrations of $\mathrm{Cu}, \mathrm{Zn}, \mathrm{Cr}$ and $\mathrm{Pb}$ in the soil collected from the mining area of Moldova Noua, used as a growth substrate for $S$. perfoliatum during the formation of the rosette of leaves $(13-18 \mathrm{BBCH})$ are relatively high, exceeding normal values, being in alert or intervention thresholds for sensitive soil use types according to Romanian legislation (Order 756/1997, Environmental Pollution Assessment Regulation) (Table 1). Chromium was the most abundant heavy metal with concentrations of $299.08 \mathrm{mg} \mathrm{kg}^{-1}$, being practically at the level of the intervention threshold of $300 \mathrm{mg} \mathrm{kg}^{-1}$ specific to sensitive types of use. High concentrations of $\mathrm{Pb}$ of $175.18 \mathrm{mg} \mathrm{kg}^{-1}$ were encountered, well above the threshold for intervention of $100 \mathrm{mg} \mathrm{kg}^{-1}$ and of $\mathrm{Cu}$ $234.66 \mathrm{mg} \mathrm{kg}^{-1}$, over to the intervention threshold $\left(200 \mathrm{mg} \mathrm{kg}^{-1}\right)$, while the $\mathrm{Zn}$ concentration is below the alert threshold $\left(300 \mathrm{mg} \mathrm{kg}^{-1}\right)$.

Table 1. Mean concentration of heavy metals in soil and reference thresholds (according with Order 756/1997, Environmental Pollution Assessment Regulation)

\begin{tabular}{|c|c|c|c|c|}
\hline \multirow{2}{*}{ Heavy metal } & \multirow{2}{*}{$\begin{array}{c}\text { Determined in soil } \\
\left(\mathrm{mg} \mathrm{kg}^{-1}\right)\end{array}$} & Normal & Alert & Reference thresholds $\left(\mathrm{mg} \mathrm{kg}^{-1}\right)$ \\
\cline { 3 - 5 } & $234.66 \pm 3.08$ & 20 & 100 & 200 \\
\hline $\mathrm{Cu}$ & $260.01 \pm 3.40$ & 100 & 300 & 600 \\
\hline $\mathrm{Zn}$ & $299.08 \pm 2.39$ & 30 & 100 & 300 \\
\hline $\mathrm{Cr}$ & $175.18 \pm 1.34$ & 20 & 50 & 100 \\
\hline $\mathrm{Pb}$ & &
\end{tabular}

Values are means $\left(\mathrm{mg} \mathrm{kg}^{-1}\right)$ of five replicate samples with standard errors

\section{Metal accumulation and distribution in plants}

The analysis of $\mathrm{Cu}$ accumulations in the root system of $S$. perfoliatum seedlings in vegetative growth stages reveals an insignificant variation of this element from 37.38 to $43.89 \mathrm{mg} \mathrm{kg}^{-1}$ fresh weight ( $\mathrm{fw}$ ) in the first two analysed phenophases, for a significant $83.89 \%$ increase in $\mathrm{Cu}$ concentration in the period from $15 \mathrm{BBCH}$ to $18 \mathrm{BBCH}$ (Table 2). At the level of petiole during the three stages the $\mathrm{Cu}$ content showed a small and insignificant variation from 18.18 to $19.62 \mathrm{mg} \mathrm{kg}^{-1} \mathrm{fw}(15 \mathrm{BBCH})$, after which it is reduced to $16.18 \mathrm{mg} \mathrm{kg}^{-1} \mathrm{fw}$ in the 8 leaves stages. In the case of the foliar limb (lamina), during the experiment there is a significant increase in $\mathrm{Cu}$ content from one stage to another, from $12.6 \mathrm{mg} \mathrm{kg}^{-1} \mathrm{fw}(13 \mathrm{BBCH})$ to $32.08 \mathrm{mg} \mathrm{kg}^{-1} \mathrm{fw}(15 \mathrm{BBCH})$ and $61.69 \mathrm{mg} \mathrm{kg}^{-1} \mathrm{fw}(18 \mathrm{BBCH})$ respectively. The rate of accumulation of $\mathrm{Cu}$ in the lamina is almost double from one phase of determination to another.

At the first determination $(13 \mathrm{BBCH})$, the root had a significantly higher $\mathrm{Cu}$ content than the other two organs. The petiole also had a significantly higher concentration than the lamina. And in the $15 \mathrm{BBCH}$ stage, there is a significantly higher content of $\mathrm{Cu}$ at the root level, associated with significantly equal values in the other organs. In the last stage, against the background of the high content of the root a significant increase in the $\mathrm{Cu}$ content of the lamina can be encountered by comparison to the petiole. 
Table 2. Heavy metals concentrations in different organs of $S$. perfoliatum for different growth stages

\begin{tabular}{|c|c|c|c|c|c|}
\hline \multirow{2}{*}{$\begin{array}{c}\text { Metal } \\
\mathrm{mg} \mathrm{kg}^{-1} \mathrm{fw}\end{array}$} & \multirow{2}{*}{ Plant organ } & \multicolumn{3}{|c|}{ Growth stage } & LSD \\
\hline & & $13 \mathrm{BBCH}$ & $15 \mathrm{BBCH}$ & $18 \mathrm{BBCH}$ & $5 \%$ \\
\hline \multirow{4}{*}{$\mathrm{Cu}$} & Root & y $37.38 \pm 0.32 \mathrm{a}$ & y $43.89 \pm 0.50 \mathrm{a}$ & $\mathrm{x} 80.71 \pm 5.48 \mathrm{a}$ & 11.06 \\
\hline & Petiole & x $18.88 \pm 0.76 b$ & $\mathrm{x} 19.62 \pm 6.92 \mathrm{~b}$ & $\mathrm{x} 16.18 \pm 0.71 \mathrm{c}$ & 13.98 \\
\hline & Lamina & z $12.60 \pm 0.44 \mathrm{c}$ & y $32.08 \pm 1.10 \mathrm{ab}$ & 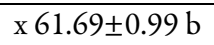 & 3.08 \\
\hline & LSD 5\% & 1.87 & 14.04 & 11.21 & \\
\hline \multirow{4}{*}{$\mathrm{Zn}$} & Root & y $53.66 \pm 3.89 a$ & xy $62.83 \pm 0.53 \mathrm{a}$ & 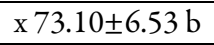 & 15.23 \\
\hline & Petiole & у $15.53 \pm 0.43 \mathrm{~b}$ & $\mathrm{x} 24.71 \pm 4.20 \mathrm{~b}$ & x $35.46 \pm 2.58 \mathrm{c}$ & 9.90 \\
\hline & Lamina & z $12.66 \pm 1.42 b$ & y $54.90 \pm 0.74 \mathrm{a}$ & $\mathrm{x} 88.88 \pm 1.51 \mathrm{a}$ & 4.40 \\
\hline & LSD 5\% & 8.32 & 8.60 & 14.35 & \\
\hline \multirow{4}{*}{$\mathrm{Cr}$} & Root & $\mathrm{z} 57.43 \pm 4.03 \mathrm{a}$ & y $84.82 \pm 0.75$ a & $\mathrm{x} 93.36 \pm 9.82 \mathrm{a}$ & 21.26 \\
\hline & Petiole & z $30.61 \pm 0.50 \mathrm{~b}$ & y $57.15 \pm 4.40 \mathrm{~b}$ & x $70.57 \pm 3.06 b$ & 10.76 \\
\hline & Lamina & z $20.04 \pm 2.91 \mathrm{c}$ & y $49.32 \pm 1.74 b$ & $x 73.89 \pm 0.53 \mathrm{ab}$ & 6.86 \\
\hline & LSD 5\% & 9.98 & 9.58 & 20.58 & \\
\hline \multirow{4}{*}{$\mathrm{Pb}$} & Root & y $33.16 \pm 2.43 \mathrm{a}$ & $\mathrm{x} 41.29 \pm 0.15 \mathrm{a}$ & $\mathrm{x} 45.13 \pm 1.83 \mathrm{~b}$ & 6.09 \\
\hline & Petiole & z $15.45 \pm 0.23 b$ & y $38.78 \pm 0.57$ b & $\mathrm{x} 42.49 \pm 1.50 \mathrm{~b}$ & 3.23 \\
\hline & Lamina & z $18.47 \pm 0.28 \mathrm{~b}$ & y $33.18 \pm 0.50 \mathrm{c}$ & 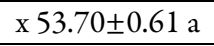 & 3.67 \\
\hline & LSD 5\% & 4.92 & 1.55 & 4.87 & \\
\hline
\end{tabular}

Values are means $\left(\mathrm{mg} \mathrm{kg}^{-1}\right)$ of tree replicate samples with standard errors. Means with different letters are significant at $\mathrm{p}<0.05$. Letters $\mathrm{a}, \mathrm{b}, \mathrm{c}$, were used for vertical comparisons and $\mathrm{x}, \mathrm{y}$, $\mathrm{z}$, for horizontal comparisons.

$\mathrm{Zn}$ accumulation in the root system of plants recorded positive, but insignificant variations from one stage to another, between 53.66 and $73.10 \mathrm{mg} \mathrm{kg}^{-1} \mathrm{fw}$. Thus, only in the stage of 8 leaves the amount of this element was significantly higher by $36.3 \%$ compared to the initial determinations. The $\mathrm{Zn}$ content in the petiole showed a gradual increase of $9-10 \mathrm{mg} \mathrm{kg}^{-1} \mathrm{fw}$ from one determination to another, associated with a significant difference only between 13 and $15 \mathrm{BBCH}$. At the lamina level, the amount of $\mathrm{Zn}$ was between 12.66 and $88.88 \mathrm{mg} \mathrm{kg}^{-1} \mathrm{fw}$, associated with significantly high variations between successive determinations. In the first stage $(13 \mathrm{BBCH})$ the amount of $\mathrm{Zn}$ in the roots was significantly higher, with more than $38.13 \mathrm{mg} \mathrm{kg}^{-1} \mathrm{fw}$ than in the petiole and lamina, which showed relatively equal levels. For $15 \mathrm{BBCH}$ stage, a higher accumulation of $\mathrm{Zn}$ was observed in the root and lamina, against the background of significant deviations from the quantity in the petiole. In the last determination, there is a clear differentiation between the three organs, so that the $\mathrm{Zn}$ content in the lamina was significantly higher than that in the root, while in the petioles the lowest value was recorded.

With regard to the $\mathrm{Cr}$ content of the dry biomass of the $S$. perfoliatum plants there is a significant variation of this element from one stage to another, against the background of an amplitude between $35.93 \mathrm{mg}$ $\mathrm{kg}^{-1} \mathrm{fw}$ for roots and $53.85 \mathrm{mg} \mathrm{kg}^{-1} \mathrm{fw}$ for lamina. In the first determination, the root system had a significantly higher $\mathrm{Zn}$ content than on the petiole and lamina. The petiole also had a significantly higher concentration than the lamina. In the $15 \mathrm{BBCH}$ stage, a significantly higher $\mathrm{Zn}$ content associated with close values in the other organs is found at the root level. In $18 \mathrm{BBCH}$, against the background of the high content of $\mathrm{Zn}$ from the roots, a significant deviation was observed only compared to petiole, i.e. significantly equal values in the two components of the leaves.

The concentration of $\mathrm{Pb}$ in the roots registered a significant variation of $24.5 \%$ only between the first two stages, associated with close values in 15 and $18 \mathrm{BBCH}$. The content of $\mathrm{Pb}$ in petiole showed a gradual and significant increase from one phenophase to another, more intense between 13 and $15 \mathrm{BBCH}$. In the case of lamina, the concentration of this heavy metal was between 18.47 and $53.70 \mathrm{mg} \mathrm{kg}^{-1} \mathrm{fw}$, associated with significantly high variations from one stage to another. At the first determination the $\mathrm{Pb}$ amount in the roots was significantly higher by $14.69-17.71 \mathrm{mg} \mathrm{kg}^{-1} \mathrm{fw}$ compared to the amount petioles and lamina which showed 
significantly equal levels. In $15 \mathrm{BBCH}$ stage, there is a significant differentiation between the three organs, so that the content of $\mathrm{Pb}$ in the roots was superior to that of petiole, while at the level of the lamina was recorded the lowest value. For the last determination, a higher accumulation of $\mathrm{Pb}$ is observed in the lamina, against the background of significant deviations from the amount of $\mathrm{Pn}$ in the petiole and in the root.

\section{Phytoremediation indexes (indexes for metal enrichment in plants)}

One of the important objectives of the research on phytoremediation of soils polluted with heavy metals is to assess the ability of plants to retrieve substrate elements and also to verify that the elements are transferred and accumulated in the various aerial organs of plants (Buscaroli, 2017).

\section{Bioaccumulation (BAF) and translocation factor (TF)}

The bioaccumulation factor is an important phytoremediation index of soils polluted with heavy metals by calculating the existing ratio between the concentration of heavy metals in the plant and the concentration of heavy metals in the soil at the same time of determination.

The data analysis concerning BAF values (Table 3 ) shows that the root system of S. perfoliatum plants exhibits a significantly superior accumulation capacity of $\mathrm{Cu}$ compared to the other analysed components, while the lamina showed a higher BAF than petiole. As for $\mathrm{Zn}$, the lamina has a higher bioaccumulation capacity, followed by the root and the petiole.

Table 3. Bioaccumulation factor (BAF) of heavy metals in different organs of S. perfoliatum

\begin{tabular}{|c|c|c|c|c|c|}
\hline \multirow{2}{*}{ Metal } & \multicolumn{4}{|c|}{ Plant organ } & LSD \\
& Root & Petiole & Lamina & Whole plant & $5 \%$ \\
\hline $\mathrm{Cu}$ & $\mathrm{x} 5.17 \pm 0.35 \mathrm{a}$ & $\mathrm{z} 1.04 \pm 0.05 \mathrm{~b}$ & $\mathrm{y} 3.95 \pm 0.06 \mathrm{a}$ & $10.17 \pm 0.34 \mathrm{a}$ & 0.72 \\
\hline $\mathrm{Zn}$ & $\mathrm{y} 2.08 \pm 0.19 \mathrm{c}$ & $\mathrm{z} 1.01 \pm 0.07 \mathrm{~b}$ & $\mathrm{x} 2.53 \pm 0.04 \mathrm{c}$ & $5.63 \pm 0.10 \mathrm{c}$ & 0.41 \\
\hline $\mathrm{Cr}$ & $\mathrm{x} 3.22 \pm 0.34 \mathrm{~b}$ & $\mathrm{y} 2.43 \pm 0.11 \mathrm{a}$ & $\mathrm{xy} 2.55 \pm 0.02 \mathrm{c}$ & $8.20 \pm 0.36 \mathrm{~b}$ & 0.69 \\
\hline $\mathrm{Pb}$ & $\mathrm{y} 2.45 \pm 0.10 \mathrm{bc}$ & $\mathrm{y} 2.30 \pm 0.08 \mathrm{a}$ & $\mathrm{x} 2.91 \pm 0.03 \mathrm{~b}$ & $7.66 \pm 0.12 \mathrm{~b}$ & 0.26 \\
\hline LSD5\% & 0.87 & 0.26 & 0.14 & 0.85 & \\
\hline
\end{tabular}

Values are means of tree replicate samples with standard errors. Means with different letters are significant at $\mathrm{p}<0.05$. Letters a, b, c, were used for vertical comparisons and $\mathrm{x}, \mathrm{y}, \mathrm{z}$, for horizontal comparisons.

Plant roots showed the highest $\mathrm{BAF}$ in $\mathrm{Cu}$ (5.17), followed by $\mathrm{Cr}$ (3.22), $\mathrm{Pb}$ (2.45) and $\mathrm{Zn}$ (2.08). In the petiole, the $\mathrm{BAF}$ values calculated for $\mathrm{Cr}$ and $\mathrm{Pb}$ were significantly higher compared to $\mathrm{Cu}$ and $\mathrm{Zn}$. The lamina recorded a high value of $\mathrm{BAF}$ for $\mathrm{Cu}$ (3.95), against the background of lower values for $\mathrm{Zn}(2.53)$ and $\mathrm{Cr}$ (2.55). At the plant level, a significantly higher accumulation capacity of $\mathrm{Cu}$ is observed, against the background of significantly equal values for $\mathrm{Pb}$ and $\mathrm{Cr}$, respectively a lower value for $\mathrm{Zn}$.

The translocation factor (TF) frequently appears in the literature as an indicator of phytoremediation of polluted soils. In general, this index refers to the ratio of accumulation of pollutants in the different aboveground parts of plants compared to the accumulation in the root system (Bose and Bhattacharyya, 2008).

The analysis of the experimental results of TF in $\mathrm{Cu}$ (Table 4) shows that the migration of this element did not show significant variations from one stage to another. The translocation of $\mathrm{Zn}$ from the root to the leaves is significantly and progressively increasing from one determination to another, so that at the end of the experiment only $36.63 \%$ of the amount of $\mathrm{Zn} /$ plant was present in the root. The same upward trend is observed for $\mathrm{TF}$ of $\mathrm{Cr}$ and $\mathrm{Pb}$, so that in the end $38.75 \%$ of the total quantity of $\mathrm{Cr}$ and $31.85 \%$ of the $\mathrm{Pb} / \mathrm{plant}$ was accumulated at the root level.

At the first determination $(13 \mathrm{BBCH})$ there is a higher translocation of $\mathrm{Pb}$ (1.0331), followed by $\mathrm{Cr}$ $(0.8837)$ and $\mathrm{Cu}(0.8425)$, respectively a reduced migration to $\mathrm{Zn}(0.5261)$ at the determination made at 15 $\mathrm{BBCH} \mathrm{TF} \mathrm{Pb}$ is significantly higher than the other elements, which recorded very close values. In the determinations carried out in $18 \mathrm{BBCH}$ stage it was found that $\mathrm{TF}$ of $\mathrm{Pb}$ was more intense than in the other elements, against the background of a lower migration of $\mathrm{Cu}$ (Table 4). 
Table 4. Translocation factor (TF) of heavy metals for studied growth stages in S. perfoliatum

\begin{tabular}{|c|c|c|c|c|}
\hline \multirow{2}{*}{ Metal } & \multicolumn{3}{|c|}{ Growth stage } & LSD \\
& \cline { 2 - 5 } $5 \%$ & $18 \mathrm{BBCH}$ & $5 \%$ \\
\hline $\mathrm{Cu}$ & $\mathrm{x} 0.8425 \pm 0.0347 \mathrm{~b}$ & $\mathrm{x} 1.1813 \pm 0.152 \mathrm{~b}$ & $\mathrm{x} 0.9739 \pm 0.0683 \mathrm{c}$ & 0.34 \\
\hline $\mathrm{Zn}$ & $\mathrm{z} 0.5261 \pm 0.0068 \mathrm{c}$ & $\mathrm{y} 1.266 \pm 0.0695 \mathrm{~b}$ & $\mathrm{x} 1.7346 \pm 0.189 \mathrm{~b}$ & 0.41 \\
\hline $\mathrm{Cr}$ & $\mathrm{z} 0.8837 \pm 0.0176 \mathrm{~b}$ & $\mathrm{y} 1.255 \pm 0.0307 \mathrm{~b}$ & $\mathrm{x} 1.5792 \pm 0.1543 \mathrm{~b}$ & 0.32 \\
\hline $\mathrm{Pb}$ & $\mathrm{z} 1.0331 \pm 0.0695 \mathrm{a}$ & $\mathrm{y} 1.7432 \pm 0.0308 \mathrm{a}$ & $\mathrm{x} 2.1398 \pm 0.1109 \mathrm{a}$ & 0.27 \\
\hline $\mathrm{LSD} \%$ & 0.13 & 0.28 & 0.45 & \\
\hline
\end{tabular}

Values are means of tree replicate samples with standard errors. Means with different letters are significant at $\mathrm{p}<0.05$. Letters a, b, c, were used for vertical comparisons and $\mathrm{x}, \mathrm{y}, \mathrm{z}$, for horizontal comparisons.

\section{Metal uptake (MU) and removal efficiency (RE)}

The analysis of metal uptake (MU) data shows that in relation to the content of $\mathrm{Cu}$ in the root system of $S$. perfoliatum plants there is an insignificant variation from 8.21 to $10.8 \mathrm{mg} \mathrm{kg}^{-1} \mathrm{dw}$ in the first two determinations, so that subsequently during the development of plants from 15 to $18 \mathrm{BBCH}$ there will be a significant increase of $12.09 \mathrm{mg} \mathrm{kg}^{-1} \mathrm{dw}$ (Table 5). In the case of petiole, the $\mathrm{Cu}$ content showed a small and insignificant variation from 3.82 to $4.49 \mathrm{mg} \mathrm{kg}^{-1} \mathrm{dw}$, and in the lamina recorded a significant increase from one determination to another, with $158.7 \%$ between 13 and $15 \mathrm{BBCH}$ and $92.4 \%$ between 15 and $18 \mathrm{BBCH}$ respectively.

Table 5. Metal uptake in $S$. perfoliatum organs for different stages of development

\begin{tabular}{|c|c|c|c|c|c|}
\hline \multirow{2}{*}{$\begin{array}{c}\text { Metal } \\
\mathrm{mg} \mathrm{kg}^{-1} \mathrm{dw}\end{array}$} & \multirow{2}{*}{ Plant organ } & \multicolumn{3}{|c|}{ Growth stage } & \multirow{2}{*}{$\begin{array}{c}\text { LSD } \\
5 \%\end{array}$} \\
\hline & & $13 \mathrm{BBCH}$ & $15 \mathrm{BBCH}$ & $18 \mathrm{BBCH}$ & \\
\hline \multirow{4}{*}{$\mathrm{Cu}$} & Root & y $8.21 \pm 0.07$ a & y $10.80 \pm 0.12 \mathrm{a}$ & $\mathrm{x} 22.89 \pm 1.55 \mathrm{a}$ & 3.11 \\
\hline & Petiole & x $3.82 \pm 0.15 b$ & $\mathrm{x} 4.49 \pm 1.58 \mathrm{~b}$ & x $3.79 \pm 0.17 \mathrm{c}$ & 3.20 \\
\hline & Lamina & $\mathrm{z} 3.15 \pm 0.11 \mathrm{c}$ & y $8.15 \pm 0.28 \mathrm{ab}$ & $x 15.68 \pm 0.25 b$ & 0.78 \\
\hline & LSD 5\% & 0.40 & 3.22 & 3.16 & \\
\hline \multirow{4}{*}{$\mathrm{Zn}$} & Root & y $11.53 \pm 0.84 \mathrm{a}$ & y $15.46 \pm 0.13 \mathrm{a}$ & $\mathrm{x} 20.73 \pm 1.85 \mathrm{a}$ & 4.07 \\
\hline & Petiole & $\mathrm{z} 3.14 \pm 0.09 \mathrm{~b}$ & y $5.66 \pm 0.96$ b & x $8.30 \pm 0.60 \mathrm{~b}$ & 2.28 \\
\hline & Lamina & $\mathrm{z} 3.16 \pm 0.35 \mathrm{~b}$ & y $13.95 \pm 0.19 a$ & $\mathrm{x} 22.60 \pm 0.38 \mathrm{a}$ & 1.12 \\
\hline & LSD 5\% & 1.83 & 1.98 & 3.97 & \\
\hline \multirow{4}{*}{$\mathrm{Cr}$} & Root & $\mathrm{z} 12.34 \pm 0.87 \mathrm{a}$ & y $20.86 \pm 0.18 \mathrm{a}$ & $\mathrm{x} 24.05 \pm 0.21 \mathrm{a}$ & 1.82 \\
\hline & Petiole & $\mathrm{z} 6.19 \pm 0.10 \mathrm{~b}$ & y $13.08 \pm 1.01 \mathrm{~b}$ & $\mathrm{x} 16.51 \pm 0.72 \mathrm{c}$ & 2.48 \\
\hline & Lamina & z $5.00 \pm 0.73 \mathrm{~b}$ & y $12.53 \pm 0.44 b$ & $\mathrm{x} 18.78 \pm 0.13 \mathrm{~b}$ & 1.72 \\
\hline & LSD 5\% & 2.27 & 2.23 & 1.52 & \\
\hline \multirow{4}{*}{$\mathrm{Pb}$} & Root & $\mathrm{z} 7.13 \pm 0.52 \mathrm{a}$ & y $10.16 \pm 0.04 \mathrm{a}$ & $\mathrm{x} 12.80 \pm 0.52 \mathrm{a}$ & 1.47 \\
\hline & Petiole & z 3.12 $\pm 0.05 c$ & y $8.88 \pm 0.13$ b & $\mathrm{x} 9.94 \pm 0.35 \mathrm{~b}$ & 0.76 \\
\hline & Lamina & $\mathrm{z} 4.61 \pm 0.07 \mathrm{~b}$ & y $8.43 \pm 0.13 \mathrm{c}$ & $\mathrm{x} 13.65 \pm 0.15 \mathrm{a}$ & 0.42 \\
\hline & LSD 5\% & 1.06 & 0.38 & 1.29 & \\
\hline
\end{tabular}

Values are means $(\mathrm{mg})$ of tree replicate samples with standard errors. Means with different letters are significant at $\mathrm{p}<0.05$. Letters $\mathrm{a}, \mathrm{b}, \mathrm{c}$, were used for vertical comparisons and $\mathrm{x}, \mathrm{y}, \mathrm{z}$, for horizontal comparisons.

The $\mathrm{Zn}$ uptake by the root system recorded positive but insignificant variations between 11.53 and $15.46 \mathrm{mg} \mathrm{kg}^{-1} \mathrm{dw}$ at the first determinations. Only in the last determination the $\mathrm{Zn}$ concentration was significantly higher by $79.8 \%$ compared to the initial value. The assimilation of $\mathrm{Zn}$ into petiole showed a progressive and significant increase of $2.5-2.6 \mathrm{mg} \mathrm{kg}^{-1} \mathrm{dw}$ from one determination to another. In lamina the $\mathrm{Zn}$ uptake recorded values between 3.16 and $22.6 \mathrm{mg} \mathrm{kg}^{-1} \mathrm{dw}$, associated with significantly high variations from one growth stage to another. In the first determination the absorption of $\mathrm{Zn}$ from the roots was significantly higher by over $8.37 \mathrm{mg} \mathrm{kg}^{-1} \mathrm{dw}$ compared to petiole and lamina which showed significantly equal levels. For stage 15 
$\mathrm{BBCH}$, a higher accumulation of $\mathrm{Zn}$ is observed in the root and lamina, against the background of significant deviations from the quantity of petiole. In the last determination, it is found that the $\mathrm{Zn}$ content in the lamina and root was significantly higher by over $12.43 \mathrm{mg} \mathrm{kg}^{-1} \mathrm{dw}$ compared to that of petiole.

Analyses of $\mathrm{Cr}$ absorption data, relative to the mass of the dried substance in the analysed vegetable parts, show a significant variation of this element from one phenophase to another, against the background of amplitude of between $10.32 \mathrm{mg} \mathrm{kg}^{-1} \mathrm{dw}$ for petiole and $13.78 \mathrm{mg} \mathrm{kg}^{-1} \mathrm{dw}$ for lamina. In $13 \mathrm{BBCH}$ stage, the root took significantly higher quantities by $6.15-7.34 \mathrm{mg} \mathrm{kg}^{-1} \mathrm{dw}$ compared to the petiole and the lamina. And in the other two determinations, the root demonstrates a high absorption capacity for $\mathrm{Cr}$.

The $\mathrm{Pb}$ concentration in the root recorded a significant positive variation of $2.64-3.03 \mathrm{mg} \mathrm{kg}^{-1} \mathrm{dw}$ from one phenophase to another. The $\mathrm{Pb}$ content of petiole had a progressive and significant increase from one determination to another, more intense between 13 and $15 \mathrm{BBCH}$. In the case of lamina, the $\mathrm{Pb}$ accumulation was between 4.61 and $13.65 \mathrm{mg} \mathrm{kg}^{-1} \mathrm{dw}$, associated with significantly high variations in determination dynamics. In the first determination $(13 \mathrm{BBCH})$ the absorption and accumulation of $\mathrm{Pb}$ from the root was significantly higher by $2.52-4.01 \mathrm{mg} \mathrm{kg}^{-1} \mathrm{dw}$ compared to the leaf parts that showed significantly different levels, (higher in lamina). In $15 \mathrm{BBCH}$ stage, there is a significant differentiation between roots and leaves, so that the $\mathrm{Pb}$ content in the root was higher than that of petiole, while at the laminate level the lowest value was recorded. At the last stage of the determination, a higher accumulation of $\mathrm{Pb}$ in the root and lamina is observed, against the background of significant deviations of $2.84-3.71 \mathrm{mg} \mathrm{kg}^{-1} \mathrm{dw}$ compared to the absorption of petiole.

The Silphium plants grown on substrate with heavy metals in leaf rosette-forming stages (13-18 BBCH) recorded an efficiency for the removal of $\mathrm{Cu}$ from the substrate between $37.52 \%$ in the initial phase and $93.35 \%$ in the last one, against the background of significant variations from one stage to another (Figure 1). Compared to the $\mathrm{Zn}$ content of the soil, there is a significant reduction in this element from one stage to another, associated with an efficiency ranging from $35.26 \%$ to $86.5 \%$. The reduction of $\mathrm{Cr}$ in soil content was between $43.13 \%$ for $13 \mathrm{BBCH}$ and $90.30 \%$ at $18 \mathrm{BBCH}$, with a significant increase in the absorption of this metal during experiment. Compared to the initial quantity of $\mathrm{Pb}$ in the soil, there is a significant decrease in this element from one determination to another, associated with an efficiency ranging from 43.68 to $89.47 \%$.

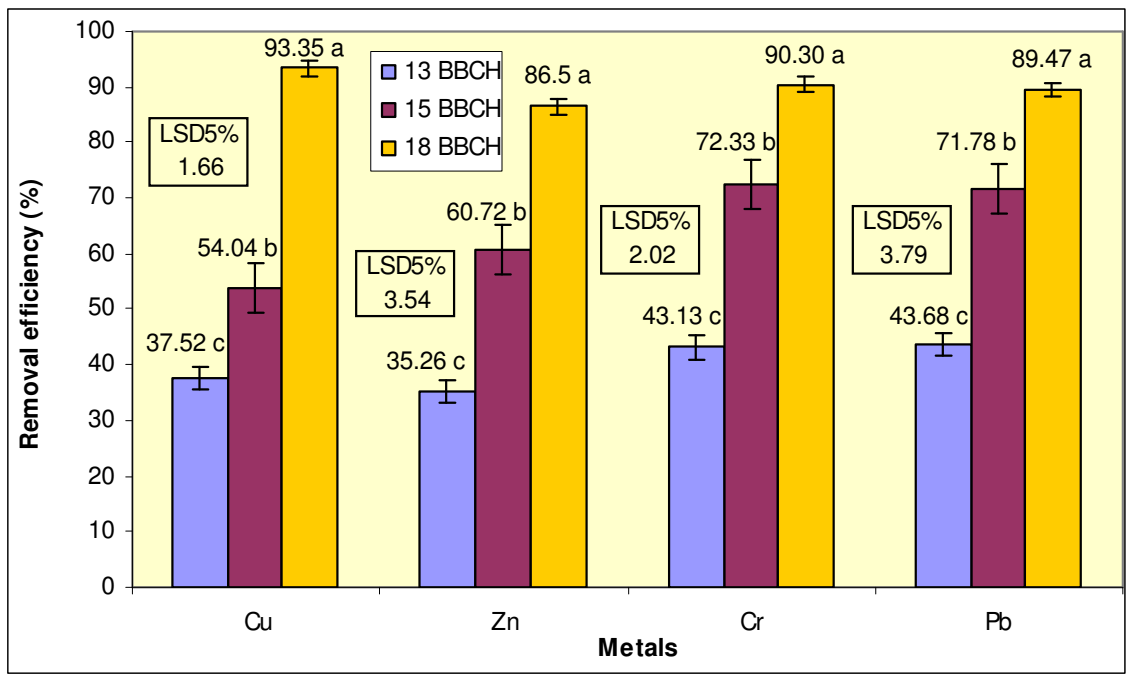

Figure 1. Removal efficiency of heavy metals by $S$. perfoliatum plants in different growth stages

${ }^{*}$ Error bars represent the standard error. In case of each metal, bars with different letters are significant at $\mathrm{p}<0.05$

Therefore, the obtained results attest to the high ability of the $S$. perfoliatum plants to take over and store important quantities of $\mathrm{Zn}, \mathrm{Cu}, \mathrm{Cr}$ and $\mathrm{Pb}$ from polluted soils close to mining explorations. The elimination efficiency is high for all studied metals, ranging from $86.5 \%(\mathrm{Zn})$ to $93.35 \%(\mathrm{Zn})$, and is in line 
with other studies (Anning and Akoto, 2018), which recommend this plant species as a potential alternative suitable for phytoremediation.

\section{Discussion}

Mining activity and its effects on soil contamination with heavy metals

Mining is widely perceived as an industrial activity that causes contamination of the environment with heavy metals (Pan et al., 2016; Pu et al., 2019). Moldova Noua is recognized for its complex polymetallic ores, copper extraction and processing (Harmanescu et al., 2011).

The Order 756/1997 (Environmental Pollution Assessment Regulation) stipulates that the "sensitive use of land is represented by its use for residential and recreational areas, for agricultural purposes, as protected areas or sanitary areas with restriction regime, as well as the areas of land provided for such uses in the future".

Framing the heavy metal concentration of the soil in the different reference thresholds is essential to deciding what measures are required for improvement. Thus, in the situations where the concentrations of pollutants in the soil are below the alert values for sensitive use of land it is not necessary to establish special measures. If the concentrations of one or more pollutants exceed the alert thresholds, but are below the intervention thresholds, it is considered that there is a potential impact on the soil. In such situations, measures must be ordered to prevent further soil pollution and to further monitor potential sources of pollution. If the concentrations of one or more pollutants exceed the intervention thresholds, these are considered to have an impact on the soil. In these situations, the use of the affected area for sensitive uses is not allowed and remedial measures will be taken (Order 756/1997, Environmental Pollution Assessment Regulation).

In this research, concentrations above the normal limits of $\mathrm{Cr}, \mathrm{Pb}, \mathrm{Cu}$ and $\mathrm{Zn}$ were determined in the agricultural soil located in the immediate vicinity of the abandoned mining site, thus demonstrating their negative impact on the environment.

Inefficient ore processing procedures have resulted in abundant accumulation of heavy metal residues in waste dumps and settling basins. Mining residues are exposed to the environment and rarely reused, leading to the mobilization and dispersion of heavy metals, sometimes causing serious pollution of soil, water and air (Zhu et al., 2018), with direct damaging effects on human health and ecosystems (Ali et al., 2013; Anning and Akoto, 2018).

Given the need for local people to cultivate agricultural land in the affected areas, these effects can be particularly problematic, requiring immediate and effective environmental remedial measures, a viable alternative being the phytoremediation (Ehsan et al., 2014; Huang et al., 2017; Wang et al., 2017; Areco et al., 2018; Feng et al., 2018)

\section{Metal accumulation and distribution in plants}

Although the scientific literature contains numerous researches on the use of species of the Asteraceae family as viable alternatives for the phytoremediation of soils polluted with heavy metals (Jadia and Fulekar, 2009; Nouri et al., 2009; Nikolic and Svetovic, 2015; Sharma et al., 2015; Sosa et al., 2016; Francis, 2017; Fu et al., 2017; Xiao et al., 2018), the species Silphium perfoliatum has been little researched from this point of view (Klimont, 2007; Majtkowski, 2010; Zhang et al., 2010).

The concept of phytoremediation was inspired by the discovery of hyperaccumulator plant species, most of which belong to the families Brassicaceae, Poaceae, Papilionaceae, Caryophyllaceae, and Asteraceae (Gawronski and Gawronska, 2007).

Silphium perfoliatum $L$. is a perennial herbaceous species (approx. 15 years), cultivated sporadically in Europe, especially as raw material for biogas production (Gansberger et al., 2015; Haag et al., 2015; Von Cossel et al., 2020) and as an ornamental plant (Titei, 2014; Jucsor and Sumalan, 2018). The plant has several clear

cultivation advantages, namely: it grows quickly, produces biomass in large quantities, shows high tolerance to 
environmental stress conditions and is relatively easy to grow without special technological investments. Most of these characteristics are referred to as mandatory attributes for plants used in the phytoremediation of soils polluted with heavy metals, and the requirements achieved so far have demonstrated the high capacity of the phytostabilization of cadmium by the genotypes of $S$. perfoliatum.

The dynamics of heavy metal accumulation detected in fresh and dry biomass at $S$. perfoliatum (Tables 2 and 5) were higher in the roots compared to aerial components (petioles and lamina) in the early stages of vegetative growth $(15 \mathrm{BBCH})$. The total amount of uptake of metals was dependent on the metal concentration in the soil, but also on the degree of development of the root system. Studies undertaken by Xiao et al. (2018), on the species of the Asteraceae family confirm that the accumulation of metals in plants has been mainly related to the total amount of soil, as well as their availability. The values of accumulation and concentration of heavy metals in plants of $S$. perfoliatum during the formation of leaf rosette are below the limits of hyperaccumulation mainly for two reasons: the quantities of metal existing in the soil and the stage of plant development.

Some of the previous research has shown that there are reduced correlations between the absorption of metals from plants and their concentrations in the soil (Keller et al., 1998; Greger, 1999). Keller et al. (1998) considered that the absorption of metals, both by roots and leaves, was not linearly correlated with the increase in the external concentration of metals. However, numerous studies show a linear, positive link between the concentration of metals in the soil and their absorption into plants (Sagner et al.,1998; Robinson et al., 2003; Boyd, 2010). An essential element of these approaches must be related to the plant species used in the tests, it being known that some species grown on heavy metal-rich substrate behave as hyperaccumulators and others, on the contrary, manifest themselves as displaying hyper tolerance.

The classification of a plant species as a heavy metal hyperaccumulator is based on the criterion of absorption and concentration of the element(s) in the foliar apparatus. Verbruggen et al. (2009) show that, depending on the level of toxicity of the metal, the values usually vary between 100 and $10,000 \mathrm{mg} \mathrm{kg}^{-1} \mathrm{dry}$ weight, thus for $\mathrm{Cd} \geq 100 ; \mathrm{Cu} ; \mathrm{Pb} ; \mathrm{Ni} \geq 1000 ; \mathrm{Zn} ; \mathrm{Mn} \geq 10,000$.

Studies carried out by Fitzgerald et al. (2003) in conjunction with the presented results show that the level of accumulation of heavy metals in plants is in a direct relationship with their concentration in the soil and that the root system of plants is their main storage organ, which shows the level of availability of substrate elements and limited mobility within the plants. However, the results showed that the leaf limb is also the main storage constituent, along with the root for $\mathrm{Zn}$ and $\mathrm{Pb}$ (Tables 2 and 5). The superior ability of aerial organs to accumulate higher amounts of heavy metals compared to the root system was also highlighted by studies carried out by Nouri et al. (2009) on different species of the Asteraceae family grown on contaminated land.

In addition to plant metal content, $\mathrm{BCF}$ and TF values are more relevant to reflect the accumulation of these elements in plant organisms and their translocation characteristics (Xiao et al., 2017).

Plant species with hyperaccumulation capacity must have a super unitary bioaccumulation factor (BAF) and translocation factor (TF) (Cluis, 2004; Wei and Zhou, 2004; Laghlimi et al., 2015). Thus, the obtained results indicate that $S$. perfoliatum presents features specific to plants with the potential for bioaccumulation of heavy metals in soils polluted with $\mathrm{Cu}, \mathrm{Zn}, \mathrm{Cr}$ and $\mathrm{Pb}$ (Table 3). Pehoiu et al. (2019 and 2020) also report high levels of accumulation of these heavy metals, specific to the Moldova Noua mining area, for two spontaneous species in the Asteraceae family (Tarraxacum officinale and Plantago major).

TF is the ratio of heavy metals concentrated in the aerial parts to those in the roots, indicating the mobility of these components inside the plant. The presented data (Table 4) indicate that the metal uptake showed high TF values, in particular for the range between 13 and $15 \mathrm{BBCH}$. The highest (super unit) values of $\mathrm{TF}$ were recorded for $\mathrm{Pb}>\mathrm{Zn}>\mathrm{Cr}$.

Several previous studies show that BAF and TF values vary quite a lot from one species to another and even within the same species (Rascio and Navari-Izzo, 2011). Furthermore, there is no clear evidence that plants with high levels of BAF have high TFs and vice versa. However, in the presented results, the metals 
showed high values of BAF in the roots and lower in the aerial parts, which is consistent with some previous research (Lu et al., 2013; Nikolic and Svetovic, 2015; Singh et al., 2017).

The plants of $S$. perfoliatum showed very high values of removal efficiency, of more than $85 \%$, for the four analyzed heavy metals. These results provide further evidence of the inherent affinities of some plant species for heavy metals and thus explain their widespread use in phytoremediation studies (Truong, 1999; Anning et al., 2013).

The existing of positive links between RE and BAF, TF show that the accumulation and translocation of metals in $S$. perfoliatum plants caused the soil decontamination. A high RE may be influenced in addition to plant characteristics (species, stage of development, metabolic activity, etc.) by the amount of soil used for testing, as well as by the duration of the experiments. This is important because, according to research carried out by Sharma and Pandey (2014) and cited by Anning and Akoto (2018), the permanent removal of heavy metals from polluted soils is the main argument for which phytoextraction is considered to be the most sustainable and effective phytoremediation technique.

\section{Conclusions}

Former mining exploitation in the area of Moldova Noua is a pollution factor with heavy metals $(\mathrm{Cu}$; $\mathrm{Zn} ; \mathrm{Cr}$ and $\mathrm{Pb}$ ) for the agricultural land in the vicinity, with concentrations at alert limits for $\mathrm{Zn}$ and $\mathrm{Cu}$, and within intervention limits for $\mathrm{Pb}$ and $\mathrm{Cr}$.

The $S$. perfoliatum plants grown on soils with heavy metals at the initial stages of leaf rosette formation have a good accumulation capacity of the four heavy metals, without showing symptoms of toxicity, but the values recorded are well below the hyperaccumulation limits, mainly due to the concentration and limited volume of soil, as well as the stage of plant development.

However, the high values determined by the calculation of the main phytoremediation indices (BAF, TF and RE) show the capacity of the $S$. perfoliatum plants for the early accumulation at the level of the roots of the four heavy metals, so that after a few, important quantities of $\mathrm{Zn}$ and $\mathrm{Pb}$ were translocated and accumulated into the lamina. The high RE values positively correlated with BAF and TF demonstrate the high decontamination capacity of heavy metal-polluted soils within this species. However, further research is needed to determine the phytoremediation capacity of $S$. perfoliatum plants in phenophases of formation and growth of stems and vegetative apparatus when the plants accumulate the greatest amount of aerial biomass.

\section{Authors' Contributions}

Conceptualization (RLS; CM; SIC; AK); Data curation (NLJ; MG; RMS) Formal analysis (RLS; MCB; DK); Funding acquisition (CM; AK; DK); Investigation (CM; NLJ; RMS; MG); Methodology (RLS; SIC; AK; MG); Project administration (CM, AK; DK); Resources (SR; CS; MCB) Software (CS; RMS); Supervision (RLS; CM; AK); Validation (MG; MCB); Visualization (SIC; RLS); Writing - original draft (RLS; SIC; RMS); Writing - review and editing (RLS; CM; SIC; RMS; MCB). All authors read and approved the final manuscript.

\section{Acknowledgements}

This work was partially supported by grant of the Interreg-IPA Cross-border Cooperation RomaniaSerbia Programme, NETMIN - RORS-308 "Forming of network for enhancing environmental protection from pollutants of mining cross border areas". 
The authors acknowledge financial support from the Politehnica University of Timisoara and Banat's University of Agricultural Sciences and Veterinary Medicine "King Michael I of Romania" from Timisoara.

\section{Conflict of Interests}

The authors declare that there are no conflicts of interest related to this article.

\section{References}

Ali H, Khan E, Sajad MA (2013). Phytoremediation of heavy metals - Concepts and applications. Chemosphere 91(7):869-881. https://doi.org/10.1016/j.chemosphere.2013.01.075.

Alloway BJ, Zhang P, Mott C, Smith SR, Chambers BJ, Nicholson FA, ... Andrews AJ (2000). The vulnerability of soils to pollution by heavy metals (Final Report for MAFF Project No. SP0127), London: MAFF.

Andra SS, Datta R, Sarkar D, Saminathan SK, Mullens CP, Bach SB (2009). Analysis of phytochelatin complexes in the lead tolerant vetiver grass [Vetiveria zizanioides (L.)] using liquid chromatography and mass spectrometry. Environmental Pollution 157:2173-2183. https://doi.org/10.1016/j.envpol.2009.02.014.

Anning AK, Korsah PE, Addo-Fordjour P (2013). Phytoremediation of wastewater with Limnocharis flava, Thalia geniculata and Typha latifolia in constructed wetlands. International Journal of Phytoremediation 15(5):452464. https://doi.org/10.1080/15226514.2012.716098

Areco MM, Haug E, Curutchet G (2018). Studies on bioremediation of $\mathrm{Zn}$ and acid waters using Botryococcus braunii. Journal of Environmental Chemical Engineering 6:3849-3859. https://doi.org/10.1016/j.jece.2018.05.041.

Azimi A, Azri A, Rezkazemi M, Ansarpour M (2017). Removal of heavy metals from industrial wastewaters: a review. ChemBioEng Reviews 4:37-59. https://doi.org/10.1002/cben.201600010.

Baker AJM, Brooks RR (1989). Terrestrial higher plants which hyperaccumulate metallic elements-a review of their distribution, ecology and phytochemistry. Biorecovery 1:81-126, http://dx.doi.org/10.1080/01904168109362867.

Bjelkova M, Gencurova V, Griga M (2011). Accumulation of cadmium by flax and linseed cultivars in field-simulated conditions:a potential for phytoremediation of Cd-contaminated soils. Industrial Crops and Products 33:761774. https://doi.org/10.1016/j.indcrop.2011.01.020.

Bose S, Bhattacharyya AK (2008). Heavy metal accumulation in wheat plant grown in soil amended with industrial sludge. Chemosphere 70:1264-1272. https://doi.org/10.1016/j.chemosphere.2007.07.062.

Boyd RS (2010). Heavy metal pollutants and chemical ecology: Exploring new frontiers. Journal of Chemical Ecology 36:46-58. https://doi.org/10.1007/s10886-009-9730-5

Buscaroli A (2017). An overview of indexes to evaluate terrestrial plants for phytoremediation purposes (Review). Ecological Indicators 82:367-380. https://doi.org/10.1016/j.ecolind.2017.07.003.

Cao X, Wahbi A, Ma L, Li B, Yang Y (2009). Immobilization of $\mathrm{Zn}, \mathrm{Cu}$ and $\mathrm{Pb}$ in contaminated soils using phosphate rock and phosphoric acid. Journal of Hazardous Material 164:555-564. https://doi.org/10.1016/j.jhazmat.2008.08.034.

Chirakkara RA, Cameselle C, Reddy KR (2016). Assessing the applicability of phytoremediation of soils with mixed organic and heavy metal contaminants. Reviews in Environmental Sciences and Biotechnology 15:299-326. https://doi.org/10.1007/s11157-016-9391-0.

Cho Y, Bolick JA, Butcher DJ (2009). Phytoremediation of lead with green onions (Allium fistulosum) and uptake of arsenic compounds by moonlight ferns (Pteris cretica cv Mayii). Microchemical Journal 91:6-8. http://dx.doi.org/10.1016/j.microc.2008.05.008.

Choińska-Pulita A, Sobolczyk-Bednareka J, Łaba W (2018). Optimization of copper, lead and cadmium biosorption onto newly isolated bacterium using a Box-Behnken design. Ecotoxicology and Environmental Safety 149:275-283. https://doi.org/10.1016/j.ecoenv.2017.12.008.

Ciulca $S$ (2006). Metodologii de experimentare în agricultura şi biologie [Experimental methodologies in agriculture and biology]. Agroprint, Timisoara, Romania. 
Cluis C (2004). Junk-greedy greens: phytoremediation as a new option for soil decontamination. Biotechnology Journal 2:61-67.

Demková L, Jezný T, Bobul'ská L (2017). Assessment of soil heavy metal pollution in a former mining area - before and after the end of mining activities. Soil and water Research 12(4):229-236. https://doi.org/10.17221/107/2016$S W R$.

Dubey S, Shri M, Gupta A, Rani V, Chakrabarty D (2018). Toxicity and detoxification of heavy metals during plant growth and metabolism. Environmental Chemistry Letters 16:1169-1192. https://doi.org/10.1007/s10311018-0741-8

Ehsan S, Ali S, Noureen S, Mahmood K, Farid M, Ishaque W, Shakoor MB, Rizwan M (2014) Citric acid assisted phytoremediation of cadmium by Brassica napus L. Ecotoxicology and Environmental Safety 106:164172. https://doi.org/10.1016/j.ecoenv.2014.03.007

Energy Industry Review (2019). Mining Industry. Retrieved 2020 November 03 from https://energyindustryreview.com/metals-mining/mining-industry-left-without-miners-lamp/

Fang YY, Cao XD, Zhao L (2012). Effects of phosphorus amendments and plant growth on the mobility of $\mathrm{Pb}, \mathrm{Cu}$, and $\mathrm{Zn}$ in a multi-metal-contaminated soil. Environmental Science and Pollution Research 19(5):1659-1667. https://doi.org/10.1007/s11356-011-0674-2.

Feng Y, Wu Y, Zhang J, Meng Q, Wang Q, Ma L, Ma X, Yang X (2018). Ectopic expression of SaNRAMP3 from Sedum alfredii enhanced cadmium root-to-shoot transport in Brassica juncea. Ecotoxicology and Environmental Safety 156:279-286. https://doi.org/10.1016/j.ecoenv.2018.03.031.

Figas A, Rolbiecki R, Tomaszewska-Sowa M (2015). Influence of drip irrigation on the height of the biennial cup plant (Silphium perfoliatum L.) from the micropropagation seedlings. Infrastructure and Ecology of Rural Areas 3, Polska Akademia Nauk, Oddział w $\quad$ wrakowie pp 786. http://dx.medra.org/10.14597/infraeco.2015.3.2.062.

Fitzgerald EJ, Caffrey JM, Nesaratnam ST, McLoughlin P (2003). Copper and lead concentrations in salt marsh plants on the Suir Estuary, Ireland. Environmental Pollution 123(1):67-74. https://doi.org/10.1016/s02697491(02)00366-4.

Francis E (2017). Phytoremediation potentials of sunflower (Helianthus annuus L.) Asteraceae on contaminated soils of abandoned dumpsites. International Journal of Scientific \& Engineering Research 8(1):1751-17157.

Fu W, Huang K, Cai HH, Li J, Zhai DL, Dai ZC, Du DL (2017). Exploring the potential of naturalized plants for phytoremediation of heavy metal contamination. International Journal of Environmental Research 11:515-521. https://doi.org/10.1007/s41742-017-0045-z.

Gansberger M, Montgomery LFR, Liebhard P (2015) Botanical characteristics, crop management and potential of Silphium perfoliatum L. as a renewable resource for biogas production: A review, Industrial Crops and Products 63:362-372. https://doi.org/10.1016/j.indcrop.2014.09.047.

Gavrilescu M (2004). Removal of heavy metal from environment by biosorbtion. Engineering in Life Sciences 4:219-232. https://doi.org/10.1002/elsc.200420026.

Gawronski SW, GAWRONSKA H (2007). Plant taxonomy for phytoremediation. In: Marmioli N, Samotokin B, Marmioli M (Eds). Advanced Science and Technology for Biological Decontamination of Sites Affected by Chemical and Radiological Nuclear Agents. Springer Nederlands, NATO Series IV, pp 79-88. https://doi.org/10.1007/978-1-4020-5520-1.

Gleba D, Borisjuk NV, Borisjuk LG, Kneer R, Poulev A, Skarzhinskaya M ... Raskin I (1999). Use of plant roots for phytoremediation and molecular farming. Proceedings of National Academy of Sciences of the United States of America 96(11):5973-5977.

Greger M (1999). Metal availability and bioconcentration in plants. In: Heavy Metal Stress in Plants. Springer, Berlin, Heidelberg. https://doi.org/10.1007/978-3-662-07745-0_1.

Gupta S, Nayek S, Saha RN, Satpati S (2008). Assessment of heavy metal accumulation in macrophyte, agricultural soil, and crop plants adjacent to discharge zone of sponge iron factory. Environmental. Geology 55(4):731-739. https://doi.org/10.1007/s00254-007-1025-y.

Haag NL, Nägele HJ, Reiss K, Biertümpfel A, Oechsner H (2015). Methane formation potential of cup plant (Silphium perfoliatum). Biomass and Bioenergy 75:126-133. https://doi.org/10.1016/j.biombioe.2015.02.012.

Hanif MA, Bhatti HN (2015). Remediation of heavy metals using easily cultivable, fast growing, and highly accumulating white rot fungi from hazardous aqueous streams. Desalination and Water Treatment 53(1):238248. https://doi.org/10.1080/19443994.2013.848413. 
Hansda A, Kumar V, Anshumali V, Usmani Z (2014). Phytoremediation of heavy metals contaminated soil using plant growth promoting rhizobacteria (PGPR): a current perspective. Recent Research in Science and Technology 6(1):131-134. http://updatepublishing.com/journal/index.php/rrst/article/view/1183.

Harmanescu M, Alda LM, Bordean DM, Gogoasa I, Gergen I (2011). Heavy metals health risk assessment for population via consumption of vegetables grown in old mining area; a case study: Banat County, Romania. Chemistry Central Journal 5:64. https://doi.org/10.1186/1752-153X-5-64.

Hemen S (2011). Metal hyperaccumulation in plants: a review focusing on phytoremediation technology. Journal of Environmental Science and Technology 4(2):118-138. https://doi.org/1-.3923/jest.2011.118.138.

Huang DL, Liu LS, Zeng GM, Xu P, Huang C, Deng LJ, Wang R, Wan J (2017). The effects of rice straw biochar on indigenous microbial community and enzymes activity in heavy metal-contaminated sediment. Chemosphere 174:545-553. https://doi.org/10.1016/j.chemosphere.2017.01.130.

Hudson-Edwards KA, Jamieson HE, Lottermoser BG (2011). Mine wastes: past, present, future. Elements 7(6):375-380. https://doi.org/10.2113/gselements.7.6.375.

IPNI (2020). International plant names index. The Royal Botanic Gardens, Kew, Harvard University Herbaria \& Libraries and Australian National Botanic Gardens. Retrieved 2020 November 06 from http://www.ipni.org.

ISO 11464 (2006). https://standards.iteh.ai/catalog/standards/iso/63199580-e1a0-4537-a141-ab923c298e27/iso$11464-2006$.

ISO 11047 (1998). https://www.iso.org/obp/ui/\#iso:std:iso:11047:ed-1:v1:en

Jadia CD, Fulekar MH (2009). Phytoremediation of heavy metals: Recent techniques. African Journal of Biotechnology 8:921-928.

Jucsor N, Sumalan R (2018). Researches concerning the potential of biomass accumulation in cup plant (Silphium perfoliatum L.). Journal of Horticulture, Forestry and Biotechnology 22(2):34-39.

Keller BEM, Lajtha K, Cristofor S (1998). Trace metal concentrations in the sediments and plants of the Danube Delta, Romania. Wetland 18(1):42-50

Klimont K (2007). Ocena przydatności wybranych gatunków roślin użytkowych do rekultywacji terenów zdewastowanych przez przemysł i gospodarkę komunalną- Assessment of the suitability of selected plant species for the remediation of land devastated by industry and municipal economy. Problemy Inżynierii Rolniczej $2(56): 27-36$.

Kramer U (2010). Metal hyperaccumulation in plants. Annual Review of Plant Biology 61:517-534. https://doi.org/10.1146/annurev-arplant-042809-112156.

Laghlimi M, Baghdad B, El Hadi H, Bouabdli, A (2015). Phytoremediation Mechanisms of heavy metal contaminated soils: a review. Open Journal of Ecology 5:375-388. http://dx.doi.org/10.4236/oje.2015.58031.

Li ZY, Ma ZW, van der Kuijp TJ, Yuan ZW, Huang L (2014). A review of soil heavy metal pollution from mines in China: pollution and health risk assessment. Science of the Total Environment 468:843-853. https://doi.org/10.1016/j.scitotenv.2013.08.090.

Liakopoulos A, Lemiere B, Michael K, Crouzet C, Laperche V, Romaidis I, ... Lassin A (2010). Environmental impacts of unmanaged solid waste at a former base metal mining and ore processing site (Kirki, Greece). Waste Management and Research 28:996-1009. https://doi.org/10.1177\%2F0734242X10375746.

Lu Y, Li X, He M, Zeng F (2013). Behavior of native species Arrhenatherum elatius (Poaceae) and Sonchus transcaspicus (Asteraceae) exposed to a heavy metal-polluted field: plant metal concentration, phytotoxicity, and detoxification responses. International Journal of Phytoremediation 15(10):924-937. https://doi.org/10.1080/15226514.2012.735288

Ma L, Sun J, Yang Z, Wang L (2015). Heavy metal contamination of agricultural soils affected by mining activities around the Gabxi River in Chenzhou Southern China. Environmental Monitoring and Assessment 187:731-740. https://doi.org/10.1007/s10661-015-4966-8.

Majtkowski W, Szulc PM, Gaca J, Mikołajczyk J (2010). Assessment of the use of Silphium perfoliatum L. in phytoremediation of sites contaminated with heavy metals. Biuletyn Instytutu Hodowli i Aklimatyzacji Roślin 256:163-169.

Martín-Lara MA, Blázquez G, Trujillo MC, Pérez A, Calero M (2014). New treatment of real electroplating wastewater containing heavy metal ions by adsorption onto olive stone. Journal of Cleaner Production 81:120-129. https://doi.org/10.1016/j.jclepro.2014.06.036. 
Meers E, Ruttens A, Hopgood M, Lesage E, Tack FMG (2005). Potential of Brassica rapa, Cannabis sativa, Helianthus annuus and Zea mays for phytoextraction of heavy metals from calcareous dredged sediment derived soils. Chemosphere 61:561-572. https://doi.org/10.1016/j.chemosphere.2005.02.026.

Meier U, Bleiholder H, Buhr L, Feller C, Hacks H, Hess M, ... Boom, TVD (2009) The BBCH system to coding the phenological growth stages of plants-history and publications. Journal of Cultivated Plants 2:41-52.

Nikolic M, Stevovic S (2015). Family Asteraceae as a sustainable planning tool in phytoremediation and its relevance in urban areas. Urban Forestry and Urban Greening 14:782-789. https://doi.org/10.1016/j.ufug.2015.08.002

Nouri J, Khorasani N, Lorestani B, Karami M, Hassani AH, Yousefi N (2009). Accumulation of heavy metals in soil and uptake by plant species with phytoremediation potential. Environmental Earth Science 59:315-323. https://doi.org/10.1007/s12665-009-0028-2.

Nowack B, Schulin R, Robinson BH (2006). Critical assessment of chelant-enhanced metal phytoextraction. Environmental Science and Technology 40(17):5225-5232. https://doi.org/10.1021/es0604919

Olguín EJ, Sánchez-Galván G (2012). Heavy metal removal in phytofiltration and phytoremediation: the need to differentiate between bioadsorption and bioaccumulation. New Biotechnology 30(1):3-8. https://doi.org/10.1016/j.nbt.2012.05.020.

Order 756/1997, Environmental Pollution Assessment Regulation (1997). Ordinul nr. 756/1997 pentru aprobarea Reglementării privind evaluarea poluării mediului. Ministerul Apelor, Pădurilor și Protecției Mediului. Retrieved 2020 October 29 from http://www.mmediu.ro/app/webroot/uploads/files/OM-184-1997-bilantde-mediu-si-OM-756-1997-evaluarea-poluarii-mediului.pdf.

Ostrowska A, Porebska G, Szczubiałka Z (2006). Limitation of Pb and Cd uptake by pine. Environmental Engineering Science 23:595-602. https://doi.org/10.1089/ees.2006.23.595.

Palmer CE, Warwick S, Keller W (2001). Brassicaceae (Cruciferae) family, plant biotechnology, and phytoremediation. International Journal of Phytoremediation 3:245-287. https://doi.org/10.1080/15226510108500059.

Pan LB, Ma J, Wang XL, Hou H (2016). Heavy metals in soils from a typical county in Shanxi Province, China: levels, $\begin{array}{llll}\text { sources and spatial distribution. } & \text { Chemosphere }\end{array}$ https://doi.org/10.1016/j.chemosphere.2015.12.049.

Pehoiu G, Radulescu C, Murarescu O, Dulama ID, Bucurica IA, Teodorescu S, Stirbescu RM (2019). Health risk assessment associated with abandoned copper and uranium mine tailings. Bulletin of Environmental Contamination and Toxicology 102(4):504-510. https://doi.org/10.1007/s00128-019-02570-9

Pehoiu G, Murarescu O, Radulescu C. Dulama ID, Teodrescu S, Stirbescu RM, ... Stanescu IG (2020). Heavy metals accumulation and translocation in native plants grown on tailing dumps and human health risk. Plant and Soil 456:405-424. https://doi.org/10.1007/s11104-020-04725-8.

Pratush A, Kumar A, Hu Z (2018). Adverse effect of heavy metals (As, Pb, Hg, and Cr) on health and their bioremediation strategies: a review. International Microbiology 21: 97-106. https://doi.org/10.1007/s10123-018-0012-3

$\mathrm{Pu}$ W, Sun J, Zhang F, Wen X, Liu W, Huang C (2019). Effects of copper mining on heavy metal contamination in a rice agrosystem in the Xiaojiang River Basin, southwest China. Acta Geochimica 38:753-773. https://doi.org/10.1007/s11631-019-00321-5.

Rascio N, Navari-Izzo F (2011). Heavy metal hyperaccumulating plants: how and why do they do it? And what makes them so interesting? Plant Science 180(2):169-181. https://doi.org/10.1016/j.plantsci.2010.08.016.

Robinson BH, Lombi E, Zhao FJ, McGrath, SP (2003). Uptake and distribution of nickel and other metals in the hyperaccumulator Berkheya coddii. New Phytologist 158:279-285. https://doi.org/10.1046/j.14698137.2003.00743x.

Sagner S, Kneer R, Wanner G, Cosson JP, Deus-Neumann B, Zenk MH (1998) Hyperaccumulation, complexation and distribution of nickel in Sebertia acuminata. Phytochemistry 47(3):339-347. https://doi.org/10.1016/S00319422(97)00593-1.

Sall ML, Diaw AKD, Gningue-Sall D, Aaron SE, Aaron JJ (2020) Toxic heavy metals: impact on the environment and human health, and treatment with conducting organic polymers, a review. Environ Sciences and Pollution Research 27:29927-29942. https://doi.org/10.1007/s11356-020-09354-3.

Sharma S, Singh B, Manchanda VK (2015). Phytoremediation: role of terrestrial plants and aquatic macrophytes in the remediation of radionuclides and heavy metal contaminated soil and water. Environmental Science and Pollution Research 22:946-962. https://doi.org/10.1007/s11356-014-3635-8.

Shen X, Chi Y, Xiong K (2019) The effect of heavy metal contamination on humans and animals in the vicinity of a zinc smelting facility. PLoS One 14(10):e0207423. https://doi.org/10.1371/journal.pone.0207423 
Shi X, Zhang X, Chen G, Chen Y, Wang L, Shan X (2011). Seedling growth and metal accumulation of selected woody species in copper and lead/zinc mine tailings. Journal of Environmental Sciences 23(2):266-274. https://doi.org/10.1016/S1001-0742(10)60402-0

Shri M, Dave R, Diwedi S, Shukla D, Kesari R, Tripathi RD, Trivedi PK, Chakrabarty D (2014) Heterologous expression of Ceratophyllum demersum phytochelatin synthase, CdPCS1, in rice leads to lower arsenic accumulation in grain. Scientific Report 4:5784. https://doi.org/10.1038/srep05784

Singh M, Kumar J, Singh S, Singh VP, Prasad SM, Singh MPV (2015). Adaptation strategies of plants against heavy metal toxicity: a short review. Biochemistry and Pharmacology 4:161. https://doi.org/10.4172/2167-0501.1000161

Singh N, Kaur M, Katnoria JK (2017). Analysis on bioaccumulation of metals in aquatic environment of Beas River Basin: A case study from Kanjli wetland. GeoHealth 1:93-105. https://doi.org/10.1002/2017GH000062.

Sosa M, Salazar MJ, Zygadlo JA, Wannaz ED (2016). Effects of Pb in Tagetes minuta L. (Asteraceae) leaves and its relationship with volatile compounds. Industrial Crops and Products 82:37-43. https://doi.org/10.1016/j.indcrop.2015.12.011.

Stanislawska-Glubiak E, Korzeniowska J, Kocon A (2015). Effect of peat on the accumulation and translocation of heavy metals by maize grown in contaminated soils. Environmental Science and Pollution Research 22(6):4706-4714. https://doi.org/10.1007/s11356-014-3706-X

Tripathi P, Mishra A, Dwivedi S, Chakrabarty D, Trivedi PK, Singh RP, Tripathi RD (2012). Differential response of oxidative stress and thiol metabolism in contrasting rice genotypes for arsenic tolerance. Ecotoxicology and Environmental Safety 79:189-198. https://doi.org/10.1016/j.ecoenv.2011.12.019

Titei V (2014)-Biological peculiarities of cup plant (Silphium perfoliatum L.) and utilization possibilities in the Republic of Moldova. Scientific papers. Agronomy Series 57(1).

Truong P (1999). Vetiver grass technology for mine rehabilitation. In: Chamchalow N, Vessabutr S (Eds). Office of the Royal Development Board. Tech Bull No 1999/2, PRVN/RDPB, Bangkok, Thailand.

Verbruggen N, Hermans C, Schat H (2009). Molecular mechanisms of metal hyperaccumulation in plants. New Phytologist 181:759-776. https://doi.org/10.1111/j.1469-8137.2008.02748.X

Von Cossel M, Amarysti C, Wilhelm H, Priya N, Winkler B, Hoerner L (2020). The replacement of maize (Zea mays L.) by cup plant (Silphium perfoliatum L.) as biogas substrate and its implications for the energy and material flows of a large biogas plant. Biofuels Bioproducts and Biorefinering 14:152-179. https://doi.org/10.1002/bbb.2084.

Wang T, Sun H (2013). Biosorption of heavy metals from aqueous solution by UV-mutant Bacillus subtilis. Environmental Science Pollution Research 20:7450-7463. https://doi.org/10.1007/s11356-013-1767$X$

Wang SQ, Wei SH, Chen YQ, Mihajhov L (2017). Comparison of soybean cultivars enriching Cd and the application foreground of the low-accumulating cultivar in production. Polish Journal of Environmental Studies 26:12991304. https://doi.org/10.15244/pjoes/67576

Wei SH, Zhou QX (2004). Identification of weed species with hyperaccumulative characteristics of heavy metals. Progress in Natural Sciences 14:495-503. https://doi.org/10.1080/10020070412331343851.

Wei S, Li Y, Zhou Q, Srivastava M, Chiu S, Zhan J, ... Sun T (2010). Effect of fertilizer amendments on phytoremediation of Cd-contaminated soil by a newly discovered hyperaccumulator Solanum nigrum L. Journal of Hazardous Material 176:269-273. https://doi.org/10.1016/j.jhazmat.2009.11.023.

Weis JS, Weis P (2004). Metal uptake, transport and release by wetland plants: implications for phytoremediation and restoration. Environment International 30:685-700. https://doi.org/10.1016/j.envint.2003.11.002.

Xiao R, Shen F, Du J, Li R, Lahori AH, Zhang Z (2018). Screening of native plants from wasteland surrounding a Zn smelter in Feng County China, for phytoremediation. Ecotoxicology and Environmental Safety 162:178-183. https://doi.org/10.1016/j.ecoenv.2018.06.095.

Yang Q, Li Z, Lu X, Duan Q, Huang L, Bi J (2018). A review of soil heavy metal pollution from industrial and agricultural regions in China: Pollution and risk assessment. Science of The Total Environment 642(15):690-700. https://doi.org/10.1016/j.scitotenv.2018.06.068.

Yoon J, Cao X, Zhou Q, Ma LQ (2006). Accumulation of Pb, Cu, and $\mathrm{Zn}$ in native plants growing on a contaminated Florida site. Science of the Total Environment 368:456-464. https://doi.org/10.1016/j.scitotenv.2006.01.016.

Yu JG, Zhao XH, Yu LY, Jiao FP, Jiang JH, Chen XQ (2013) Removal, recovery and enrichment of metals from aqueous solutions using carbon nanotubes. Journal of Radioanalytical Nuclear Chemistry. https://doi.org/10.1007/s10967-013-2818y. 
Yu C, Peng X, Yan H, Li X, Zhou Z, Yan T (2015). Phytoremediation ability of Solanum nigrum L. to Cd-Contaminated soils with high levels of $\mathrm{Cu}, \mathrm{Zn}$, and Pb. Water Air and Soil Pollution 226:15. https://doi.org/10.1007/s11270015-2424-4

Zhang X, Xia H, Li Z, Zhuang P, Gao B (2010). Potential of four forage grasses in remediation of Cd and Zn contaminated soils. Bioresource Technology 101:2063-2066.

Zhang Q, Li Y, Phanlavong P, Wang Z, Jiao T, Qiu H, Peng Q (2017). Highly efficient and rapid fluoride scavenger using an acid/base tolerant zirconium phosphate nanoflake: Behaviour and mechanism. Journal of Cleaner Production 161:317-326. https://doi.org/10.1016/j.jclepo.2017.05.120.

Zhang Q, Li Y, Yang Q, Chen H, Chen X, Jiao T, Peng Q (2018a). Distinguished Cr (VI) capture with rapid and superior capability using polydopamine microsphere: Behavior and mechanism. Journal of Hazardous Material 342:732. https://doi.org/10.1016/j.jhazmat.2017.08.061.

Zhang X, Li M, Yang H, Li X, Cui Z (2018b). Physiological response of Suaeda glauca and Arabidopsis thaliana in phytoremediation of heavy metals. Journal of Environmental Management 223(1):132-139. https://doi.org/10.1016/j.jenvman.2018.06.025.

Zhi-Xin N, Sun LN, Sun TH, Li YS, Wang H (2007) Evaluation of phytoextracting cadmium and lead by sunflower, ricinus, alfalfa and mustard in hydroponic culture. Journal of Environmental Sciences 19:961-967. https://doi.org/10.1016/s1001-0742(07)60158-2.

Zhu G, Xia H, Guo Q, Song B, Zheng G, Zhang Z, ... Okoli CP (2018). Heavy metal contents and enrichment characteristics of dominant plants in wasteland of the downstream of a lead-zinc mining area in Guangxi, Southwest China. Ecotoxicology and Environmental Safety 151:266-271. https://doi.org/10.1016/j.ecoenv.2018.01.011
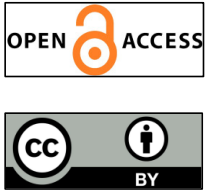

The journal offers free, immediate, and unrestricted access to peer-reviewed research and scholarly work. Users are allowed to read, download, copy, distribute, print, search, or link to the full texts of the articles, or use them for any other lawful purpose, without asking prior permission from the publisher or the author.

License - Articles published in Notulae Botanicae Horti Agrobotanici Cluj-Napoca are Open-Access, distributed under the terms and conditions of the Creative Commons Attribution (CC BY 4.0) License.

(C) Articles by the authors; UASVM, Cluj-Napoca, Romania. The journal allows the author(s) to hold the copyright/to retain publishing rights without restriction. 